\title{
Characteristics of Scylla spp. (Decapoda: Portunidae) and Their Mangrove Forest Habitat in Ngaremeduu Bay, Republic of Palau ${ }^{1}$
}

\author{
Katherine C. Ewel, ${ }^{2,3}$ Stacy Rowe ${ }^{4}$ Blake McNaughton, ${ }^{5}$ and Kimberly M. Bonine 6
}

\begin{abstract}
Three species of mangrove crabs (Scylla spp.) were captured in live traps in Ngaremeduu Bay on the island of Babeldaob, Republic of Palau. Most were $S$. serrata, but one individual each of $S$. olivacea and $S$. paramamosain was also trapped, establishing existence of a biogeographic gradient in mangrove crab species diversity across the Micronesian archipelago. Species composition of mangrove trees along transects around the bay and along the three major tributaries was similar to that of other Micronesian islands, although trees are smaller in Palau. For 17 months in 1999-2000, crabs were trapped in the bay and captured by hand along the transects; they were trapped again for 1 month in 2004. Characteristics of the crabs and of burrows encountered along the transects suggested that only S. serrata was captured in 1999-2000 and that population density of this species was $40 \mathrm{crabs} \mathrm{ha}^{-1}$. Carapace widths for the 159 crabs captured during the entire study did not differ significantly over the 4-yr span, and averaged $153 \mathrm{~mm}$ for males and $137 \mathrm{~mm}$ for females. However, average carapace widths for the largest quartile of crabs declined significantly from $174 \mathrm{~mm}$ to $171 \mathrm{~mm}$ across the study period. Catch per unit effort was $0.28 \mathrm{crab}$ per trap night in 1999-2000 and 0.45 in 2004. Although large crabs are still available in Ngaremeduu Bay, current regulations may not be sufficient to keep populations from decreasing gradually in size, especially in the face of increasing harvest pressure on the island of Babeldaob.
\end{abstract}

Mangrove crabs (Scylla spp. [also called mud crabs]) are an important component of local economies and mangrove forest food webs throughout the Indo-Pacific. They often exceed $200 \mathrm{~mm}$ in carapace width and are commonly harvested as a source of food and income throughout their range. In the Republic of Palau ( $\left.7^{\circ} 29^{\prime} \mathrm{N}, 134^{\circ} 31^{\prime} \mathrm{E}\right)$,

${ }^{1}$ Participation of K.M.B. was made possible by a grant from the John D. and Catherine T. MacArthur Foundation (no. 97-49885A-WER; B. Singer, R. Naylor, K. Ewel, and S. Abraham, principal investigators). The work performed in this study complied with the current laws of the Republic of Palau. Manuscript accepted 28 November 2007.

2 Corresponding author.

${ }^{3}$ U.S. Department of Agriculture Forest Service, Pacific Southwest Research Station, Institute of Pacific Islands Forestry, Hilo, Hawai'i 96720. Current address:

Pacific Science (2009), vol. 63, no. 1:15-26

(C) 2009 by University of Hawai'i Press

All rights reserved the westernmost country in the Pacific island group of Micronesia, mangrove crabs are regularly trapped in Ngaremeduu Bay, a large, shallow, mangrove-lined estuary on the island of Babeldaob, at $333 \mathrm{~km}^{2}$ the second largest island in Micronesia (Figure 1). In spite of the popularity of these crabs as food items, little is known about them in

School of Forest Resources and Conservation, University of Florida, Gainesville, Florida 32611 (e-mail: kewel@ ufl.edu).

${ }^{4}$ Ngatpang State Government, Republic of Palau 96940. Current address: National Oceanic and Atmospheric Administration, Northeast Fisheries Science Center, Woods Hole Laboratory, Woods Hole, Massachusetts 02543 .

${ }^{5}$ Palau Department of Marine Resources, Republic of Palau 96940. Current address: Tropical Conservation Biology and Environmental Science, University of Hawai'i at Hilo, Hilo, Hawai'i 96720.

${ }^{6}$ Institute for International Studies, Center for Environmental Science and Policy, Stanford University, Stanford, California 94305-6055. Current address: Conservation Strategy Fund, 1160 G Street, Arcata, California 95521 . 

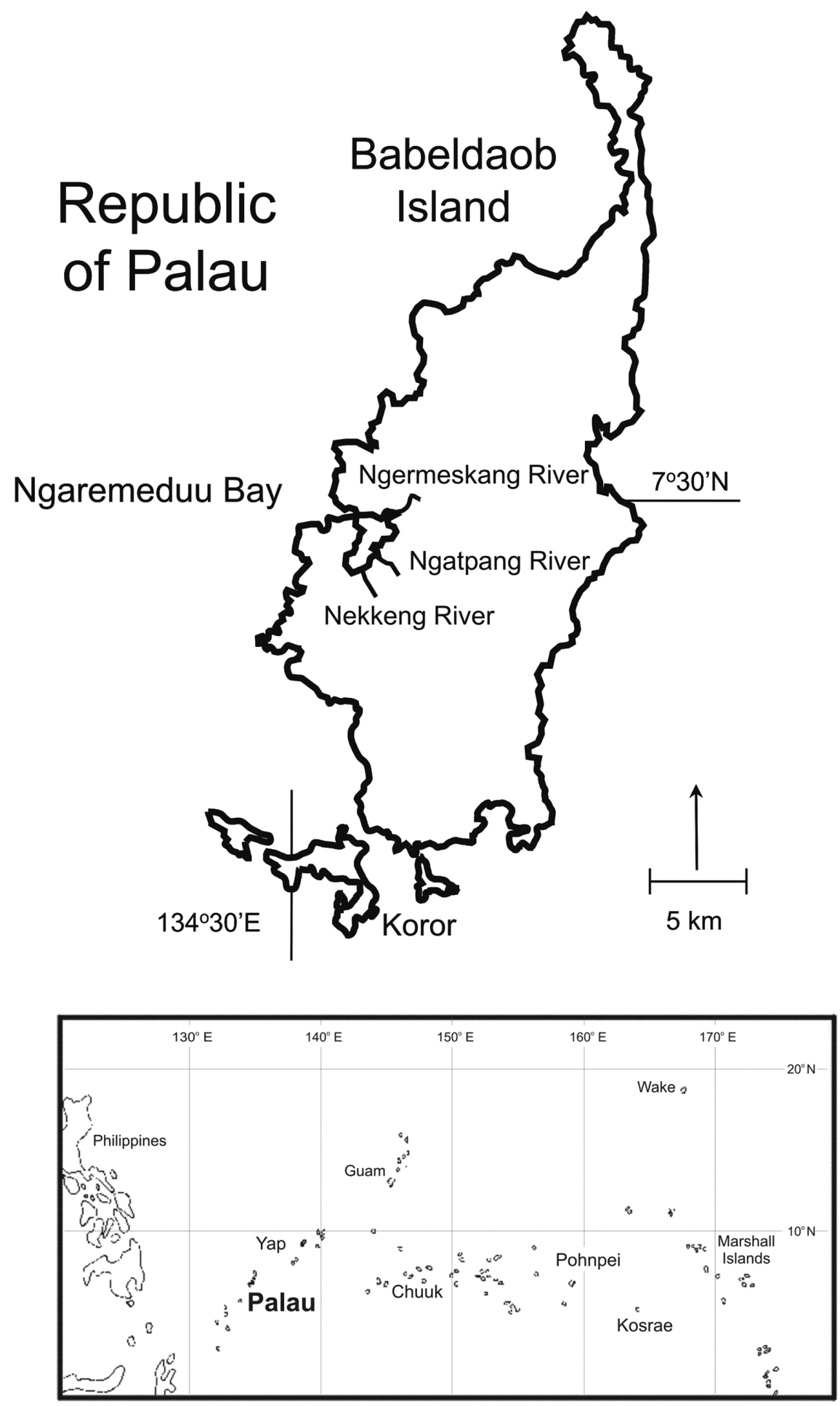

FIgURE 1. Locations of Ngaremeduu Bay and its three main tributaries on the island of Babeldaob and of the Republic of Palau in the Micronesian archipelago. 
Palau and in many other parts of their range. This island nation is located in a regional "hotspot" of biodiversity (sensu Atherton 2007), and, like the rest of the Micronesian islands, has an economy that depends heavily on its renewable natural resources. Understanding more about ecological relationships involving mangrove crabs may be useful not only for Palauan resource managers but for understanding how this important organism varies in its population characteristics and habitat preferences throughout its range. The purpose of this paper is to summarize major characteristics of mangrove crabs and their habitat in Palau.

Adult mangrove crabs spend most of their time in sheltered estuaries, bays, and the lower reaches of rivers and tidal creeks; they often dig burrows, which they may use as refuges or for mating (Brown 1993). They are generalist feeders and seldom move more than 1-2 km from a given site (Hyland et al. 1984, Benstead et al. 2006, Le Vay et al. 2007, Bonine et al. 2008; D. Perrine, 1978, unpubl. data on Scylla serrata on Ponape).

Shortly before our study began, a taxonomic revision subdivided Scylla serrata, a designation that for many years included all mangrove crabs (Stephenson and Campbell 1960), into four species: S. serrata, S. paramamosain, S. olivacea, and S. tranquebarica (Keenan et al. 1998). These four species overlap throughout their range and are likely to be subjected to similar harvest pressures. Nevertheless, the taxonomic confusion that prevailed for many years reduces what is definitively known about the characteristics of any one species of crab, of communities of two or more species, and of the habitats of different species. Studies from sites where only one species occurs or, more recently, where coexisting species could be discriminated, have shed some light on differences in population characteristics and habitat preferences among the four species. For instance, studies in South Africa (Robertson and Piper 1991) and Kosrae, Federated States of Micronesia (Benstead et al. 2006, Bonine et al. 2008), provide information on $S$. serrata where it is known to be the only species. Differences in growth rates, habitat preferences, and responses to exploitation are now avail- able for overlapping populations of $S$. paramamosain and S. olivacea in Vietnam (Walton et al. 2006b, Le Vay et al. 2007) and Thailand (Overton and Macintosh 2002) and for $S$. tranquebarica, S. olivacea, and S. serrata in the Philippines (Walton et al. 2006a).

This study began as an effort to estimate the population size and individual size characteristics of mangrove crabs at a time when we believed $S$. serrata to be the only species. We also wanted to characterize mangrove forest habitat, particularly where the crabs construct burrows. Because of the opening of Palau's new capitol complex on Babeldaob and the imminent completion of a road around the island, it was clear that the human population and general traffic on that island would soon increase, subjecting Ngaremeduu Bay to more environmental disturbance and its mangrove crabs to greater harvest pressure. Federal regulations in force at the end of the twentieth century already prohibited the harvest of any mangrove crabs with a carapace width less than 6 inches (approximately $152 \mathrm{~mm}$ ) and of all egg-bearing females, as well as the export of any crabs. Nevertheless, experienced fishers around the bay remarked at that time that it was increasingly difficult to trap mangrove crabs of any size. Understanding the status of the crab population and major characteristics of areas where crab burrows occur could assist future resource managers in protecting key areas, evaluating environmental impacts, and designing appropriate management and conservation protocols. Our study was later extended to determine which species of mangrove crabs were present in the bay and the average sizes of crabs in these species. In addition to providing information useful to resource managers on Palau, the results of this study also expand our understanding of the distribution of different species of mangrove crabs throughout the Indo-Pacific and provide a basis for interpreting the status of mangrove crab populations in other countries, particularly elsewhere in Micronesia.

\section{MATERIALS AND METHODS}

We first trapped mangrove crabs from January 1999 through May 2000 in Ngaremeduu Bay. At the same time, we obtained baseline 
information about habitat characteristics. We trapped again in May 2004.

\section{Study Site}

Ngaremeduu Bay is shallow, with extensive intertidal and subtidal mudflats, and it is lined by mangrove forests. At 1,450 ha, it is the largest estuary in Micronesia. Three rivers flow into the bay: Ngermeskang, Ngatpang (also called Ngetpang and Ngchelotel), and Nekkeng (also called Tabecheding) (Figure 1). Names and spellings of place names are notably variable in Palau, in part a result of having had four different foreign countries administering the islands' affairs from 1710 until independence in 1994 (see Crombie and Pregill 1999). By the same token, "Ngeremeduu" is an alternative spelling of the name of the bay, and "Belau" is frequently used as the name of the country. We have chosen the river names used by our local $\mathrm{Pa}$ lauan field assistants.

In 1999, the Ngaremeduu Bay Conservation Area was established "to protect and conserve the natural resources of the Ngaremeduu Conservation Area, while allowing for sustainable development opportunities" (Ridep-Morris 2000:1). The mangroves around Ngaremeduu Bay account for nearly half of Palau's total mangrove estate (Cole et al. 1987). An estimated 19 species of mangroves are found throughout Palau (N. Duke, pers. comm.). In 2002, a 25-ha corner of the bay was declared a permanent crab conservation area. Since 2004, the crab fishery in most of the bay has been closed to harvesting from April to August each year, and the restrictions on catch listed earlier continue in force for the rest of the year.

\section{Habitat Characteristics}

In January 1999-May 2000, we laid out belt transects around Ngaremeduu Bay to determine general characteristics of the mangrove forest, including crab burrow density. These transects were 3 by $33.3 \mathrm{~m}$ and were established during low tide. Daily starting points were selected randomly, designating which river would be visited, distance upstream from the bay, starting azimuth (0-360), and initial distance from shore $(0-20 \mathrm{~m})$. At the end of each transect, a new random azimuth was chosen along with a randomly selected distance $(0-20 \mathrm{~m})$ to the beginning of the next transect.

Within each belt transect, soil depth $(\mathrm{cm})$ was measured by inserting a meter stick as deep as possible. Soil type was classified as silt with organic matter or sandy by visually inspecting it and rubbing it between the fingers. Tree height at $0,10,20$, and $30 \mathrm{~m}$ along the transect was estimated as less than $5 \mathrm{~m}$, $5 \mathrm{~m}$ to $10 \mathrm{~m}$, or greater than $10 \mathrm{~m}$. Average heights were calculated for each transect. Trees greater than $10 \mathrm{~cm}$ in diameter and areas of dense roots or pneumatophores ("root thickets") were noted by species as they were encountered along the transect. Logs were characterized as being small (10$20 \mathrm{~cm}$ diameter) or large ( $>20 \mathrm{~cm}$ diameter) and as lying on or above the ground. Presence of any mangrove crab burrow was noted for each $10 \mathrm{~m}$ interval along the transect. They were easy to locate because of their size; no other organism creates large burrows in Micronesian mangrove forests.

In addition, seven burrows that were located in accessible areas of the mangrove forest along both the Nekkeng and Ngatpang rivers were periodically monitored for condition and crab activity from January 2000 through May 2000. Maximum width was measured for all crab burrows located on transects, the seven crab burrows that were monitored, and additional burrows found adjacent to transects.

\section{Mangrove Crab Populations}

Mangrove crabs were captured as part of two different trapping regimes over a 5 yr period. One to three times a month from January 1999 to May 2000, four to 11 traps were set in the bay haphazardly and about $20 \mathrm{~m}$ apart, according to local custom, and left to soak overnight. Numbers varied because of occasional trap loss and the difficulty in getting replacements. Crab traps measured approximately 1 by 0.5 by $0.3 \mathrm{~m}$ and were constructed from $2.5 \mathrm{~cm}$ wire mesh. They were 
baited with locally caught tuna or reef fish placed in perforated aluminum cans that allowed the scent of the fish to diffuse but prevented small crabs and fish from eating the bait. Sex and carapace width (distance from tip to tip of anterolateral spines) were recorded for each crab caught. Each crab was tagged by using superglue to affix a unique combination of six colored beads (beads were $6 \mathrm{~mm}$ in diameter and were affixed in three pairs) to the middle of its carapace, and it was released in the same spot where it was caught.

The sex and carapace width of any crab found when transects were being searched for burrows were recorded. A crab was removed from a burrow by gently inserting a machete along the burrow wall and lifting the crab out; no burrow was longer than a machete held at arm's length. Starting in June 1999, crabs found in burrows were tagged as described earlier.

We calculated overall burrow density in the 520 ha of mangrove forests around Ngaremeduu Bay by weighting the density observed on transects around each river by the amount of mangrove forest around that river as indicated on a vegetation map (Cole et al. 1987).

The second trapping regime was conducted over seven nights in May 2004, when 14-18 traps were set around the bay at least 50-100 $\mathrm{m}$ apart. The area trapped included the 1999-2000 trapping sites. Traps were often placed in front of small channels $(1 \mathrm{~m}$ to several meters across) emerging from mangrove stands. The traps varied in size from 0.5 by 0.5 by $0.25 \mathrm{~m}$ to 1 by 0.5 by $0.3 \mathrm{~m}$ and were baited as described earlier. Crabs were tagged with Hallprint T-bar tags using a tagging gun. Trapping was conducted by permission throughout the closed season described earlier, so few others were fishing in the bay.

\section{Data Analysis}

Generalized Linear Models procedures (GENMOD, SAS Institute, Inc. 2000) were used to examine differences in characteristics of mangrove forests among the three rivers.
Significant differences among means for continuous variables (tree height and soil depth) were determined from the chi-square distribution $(P=.05)$. A natural $\log$ transformation was applied to tree height data, which were not normally distributed and failed Levene's homogeneity of variance test. The Poisson Regression in Log Linear Model was utilized to examine differences among rivers for count data: numbers of crab burrows, trees by species, and small or large logs either on the ground or suspended above the ground. Bonferroni's Method (Milliken and Johnson 1992) was used to adjust the significance level necessary to find differences among them $(P=.0167)$. Chi-square analysis $(P<.05)$ determined whether $(1)$ transects with sandy soils were particularly common along any of the rivers, (2) transects with burrows were evenly distributed among the three rivers, and (3) transects with sandy soils were more likely to have burrows than transects with silt and organic matter. Only significant results of these tests are discussed here.

Differences in carapace widths were tested using PROC TTEST in Version 9.1 of the SAS System for Windows (SAS Institute, Inc. 2000-2004). The Satterthwaite approximation was used to calculate degrees of freedom for samples with unequal variance. Differences in carapace width between the largest quartiles of different groups of crabs were also tested in some cases to reduce any bias that might be caused by the recruitment of large numbers of small crabs into a trappable size class. Significance of differences in burrow widths with and without crabs was determined by a $t$-test calculated by hand.

\section{RESULTS}

\section{Mangrove Forest Habitat}

Eight of the 19 species of mangrove trees known to occur in Palau were found on the 121 transects that we established around Ngaremeduu Bay. In order of decreasing frequency (with number of trees per $100 \mathrm{~m}^{2}$ in parentheses), they included Rhizophora apiculata (5.18), Xylocarpus granatum (2.45), Bruguiera gymnorbiza (1.03), Ceriops tagal (0.84), 
Lumnitzera littoralis (0.34), Nypa fruticans (0.23), Sonneratia alba (0.07), and Rhizophora stylosa (0.01).

In 1999-2000, 48 crab burrows were found on 38 of the 121 transects in addition to the seven monitored burrows and two others encountered adjacent to transects early in the study. Average width of all $57 \mathrm{crab}$ burrows was $547 \mathrm{~mm}(\mathrm{SD}=191)$, ranging from 300 to $1,100 \mathrm{~mm}$. Crabs were found in 18 burrows; there was no significant difference in size between burrows with and without crabs $(t=1.49, \mathrm{df}=55, P=.14)$. Burrows were not preferentially associated with any of the most common trees; however, none of the $N$. fruticans and $R$. mucronata trees was found on transects with burrows, whereas more than half the $S$. alba trees were, in spite of the relative scarcity of this species.

Overall burrow density was 0.40 per 100 $\mathrm{m}^{2}(\mathrm{SE}=0.06)$. It was significantly greater along the Nekkeng River than along the Ngatpang River, whereas densities along the Ngermeskang River were intermediate ( $\mathrm{Ta}$ ble 1). The Nekkeng River had significantly deeper soils, although both canopy openness and tree height were intermediate compared with the forests on the other two rivers. More logs were lying on the forest floor than in the other two forests. In particular, large logs lying on top of or above the ground were significantly more likely to be found along the Nekkeng River and on transects with burrows.

Crabs were observed in six of the seven regularly monitored burrows; one burrow was vacant on all visits. One of the burrows was occupied on two separate occasions by different crabs, and on three occasions two crabs were found in the same burrow, once in a monitored burrow and twice in burrows located on the transects. On all three occasions, one crab was a male and one was a female, but they were not coupling when they were found. To our knowledge, we never encountered the same crab twice in a burrow.

Shallow burrows that were initially active were filled in completely in as little as 2 months. Deeper burrows that were initially active showed signs of filling in (loose sediment was accumulating inside) after 3 months.

\section{Mangrove Crab Characteristics}

Catch per unit effort was 0.28 crab per trap night $(\mathrm{SE}=0.05)$ in 1999-2000 and 0.45 crab per trap night $(\mathrm{SE}=1.32)$ in 2004.

The 97 crabs collected in 1999-2000 were

TABLE 1

Characteristics of Mangrove Forests around Ngaremeduu Bay, Republic of Palau, Based on $100 \mathrm{~m}^{2}$ Transects

\begin{tabular}{|c|c|c|c|c|}
\hline \multirow[b]{2}{*}{ Parameters $^{a}$} & \multirow[b]{2}{*}{ All Rivers } & \multicolumn{3}{|c|}{ Individual Rivers ${ }^{b}$} \\
\hline & & Ngermeskang & Ngatpang & Nekkeng \\
\hline Number of transects & 121 & 31 & 49 & 41 \\
\hline Area of forest (ha) & 520 & 147 & 200 & 173 \\
\hline Mean soil depth $(\mathrm{cm})$ & 56 & $48^{b}$ & $52^{b}$ & $66^{a}$ \\
\hline \multicolumn{5}{|l|}{ Number of transects with: } \\
\hline Sandy soil & 13 & 0 & 12 & 1 \\
\hline Silt + organic matter & 101 & 29 & 34 & 38 \\
\hline Mixed soil types & 7 & 2 & 3 & 2 \\
\hline Burrows per hectare & 40 & $45^{a, b}$ & $18^{b}$ & $61^{a}$ \\
\hline Mean canopy openness & 0.6 & $0.4^{b}$ & $0.7^{a}$ & $0.6^{a, b}$ \\
\hline Mean tree height (m) & 9 & $13^{a}$ & $6^{c}$ & $10^{b}$ \\
\hline Number of logs per hectare & 354 & $323^{b}$ & $253^{b}$ & $498^{a}$ \\
\hline Number of logs $<20 \mathrm{~cm}$ diameter, on the surface & 31 & $23^{b}$ & $16^{b}$ & $54^{a}$ \\
\hline
\end{tabular}

${ }^{a}$ Environmental characteristics are averages of values within transects or number of transects with a given characteristic.

${ }^{b}$ Different lowercase letters indicate significant differences among rivers $(P<.05)$. 
TABLE 2

Numbers and Sizes of Crabs Captured in 1999-2000 in Ngaremeduu Bay (in Traps) and in the Mangrove Forest (by Hand from Burrows or on the Soil Surface)

\begin{tabular}{lll}
\hline \hline & \multicolumn{2}{c}{$\begin{array}{c}\text { Mean Carapace } \\
\text { Width } \pm \text { SE }(\mathrm{mm})^{a}\end{array}$} \\
\cline { 2 - 3 } $\begin{array}{l}\text { Source of Crabs } \\
\text { (Method of Capture) }\end{array}$ & \multicolumn{1}{c}{ Males } & Females \\
\hline All & $\begin{array}{l}152 \pm 3.3^{a} \\
(n=65)\end{array}$ & $\begin{array}{l}136 \pm 3.2^{b} \\
(n=32)\end{array}$ \\
Bay (traps) & $\begin{array}{l}151 \pm 3.9 \\
(n=51)\end{array}$ & $\begin{array}{l}139 \pm 3.6 \\
(n=26)\end{array}$ \\
Mangroves (hand) & $\begin{array}{l}155 \pm 7.0 \\
(n=14)\end{array}$ & $\begin{array}{l}124 \pm 5.7 \\
(n=6)\end{array}$ \\
\hline
\end{tabular}

${ }^{a}$ Within each gender pair, means followed by different lowercase letters are significantly different $(P<.05)$.

assumed at that time to be $S$. serrata, but some may in fact have belonged to other species. They were caught in traps in the bay (77), found in burrows (19), or encountered in the mangrove forest on the soil surface (1). The largest male captured was $200 \mathrm{~mm}$, and the largest female was $180 \mathrm{~mm}$. Males were significantly larger than females $(t=$ 3.41 , df $=85.5, P=.001$ ) (Table 2). Neither males nor females captured in the mangrove forest differed in size significantly from those trapped in the bay (males: $t=0.43, \mathrm{df}=21.6$, $P=.67$; females: $t=2.19, \mathrm{df}=9.44, P=$ $.05)$. The crabs found in burrows ranged from 100 to $185 \mathrm{~mm}$ and averaged $142 \mathrm{~mm}$ $(\mathrm{SE}=6.9)$ in width.

Among the 62 crabs that were trapped in 2004 , all but two were $S$. serrata; a female $S$. paramamosain and a male $S$. olivacea were also trapped (Table 3). Our identification of the two previously unrecorded species was facilitated by detailed color diagrams on a poster prepared by Queensland (Australia) Department of Primary Industries and Fisheries based on the genetic and morphologic analyses of Keenan et al. (1998). The characteristics highlighted on the poster are based on the cheliped spines: the propodus spines are distinct in $S$. serrata, moderate and sharp in $S$. paramamosain, and reduced and blunt in $S$. olivacea; and the carpus spines are prominent in $S$. serrata, whereas in S. paramamosain and
TABLE 3

Species, Size, and Number of Crabs Captured in Traps in Ngaremeduu Bay in 2004

\begin{tabular}{lll}
\hline \hline & \multicolumn{1}{c}{$\begin{array}{c}\text { Mean Carapace Width } \pm \mathrm{SE} \\
(\mathrm{mm})^{a}\end{array}$} \\
\cline { 2 - 3 } Species of Crab & \multicolumn{1}{c}{ Male } & Female \\
\hline All & $\begin{array}{l}155 \pm 1.9^{a} \\
(n=47)\end{array}$ & $\begin{array}{l}139 \pm 5.5^{b} \\
(n=15)\end{array}$ \\
Scylla serrata & $\begin{array}{l}155 \pm 2.0^{a} \\
(n=46)\end{array}$ & $\begin{array}{l}136 \pm 5.3^{b} \\
(n=14)\end{array}$ \\
Scylla olivacea & $\begin{array}{l}(49 \\
(n=1)\end{array}$ & \\
Scylla paramamosain & & 174 \\
& & $(n=1)$ \\
\hline
\end{tabular}

${ }^{a}$ Within each gender pair, means followed by different lowercase letters are significantly different $(P<.05)$.

S. olivacea, the carpus spines are absent or very reduced. In addition, the frontal lobes are high and rounded in $S$. serrata, high and pointed in $S$. paramamosain, and low and rounded in $S$. olivacea. The color of both $S$. serrata and $S$. paramamosain can vary from purple to green to black, depending on habitat. The putative $S$. paramamosain we captured was distinctly green, whereas $S$. olivacea is unique among the four in having rusty-red color on legs and claws (Keenan et al. 1998).

Scylla serrata males were significantly $(t=$ $3.25, \mathrm{df}=16.8, P=.005)$ larger than $\mathrm{fe}-$ males, and all males together were significantly $(t=2.68, \mathrm{df}=17.6, P=.02)$ larger than all females together. The largest male caught was $184 \mathrm{~mm}$, and the largest female caught was $174 \mathrm{~mm}$.

There were no significant differences between sizes of males or females caught in 1999-2000 and those caught in 2004 (including $S$. paramamosain and S. olivacea) (males: $t=0.71, \mathrm{df}=98.8, P=.48 ;$ females: $t=$ $0.46, \mathrm{df}=24, P=.65)$. However, the mean carapace width of the largest quartile of all crabs captured in $2004(171 \mathrm{~mm}, n=16)$ was significantly smaller than that for all crabs captured in 1999-2000 (174 mm, $n=25 ; t=2.85, \mathrm{df}=37.2, P=.007)$. Although these sample sizes are small, there were no unusually large crabs among either males or females, and the decline was consis- 
tent with a long-term trend reported by local fishers.

\section{DISCUSSION}

Mangrove crabs are found in many but not all of the Micronesian islands from Palau eastward to Kosrae, Federated States of Micronesia (FSM) (Figure 1). The islands most likely to have them are hilly or mountainous, and their mangroves border coastal plains crossed by perennial streams. Extensive mangrove stands are found on only a few of the Micronesian atolls (eroded remnants of high volcanic islands, such as in the Republic of the Marshall Islands), and mangrove crabs appear to be absent from them (e.g., Kiribati: W. Metz, pers. comm.).

Pending genetic analysis to ensure the validity of our identifications, it is likely that at least three of the four currently recognized species of mangrove crabs are found in Ngaremeduu Bay, Republic of Palau: Scylla olivacea, S. paramamosain, and $S$. serrata. Throughout the rest of the Indo-Pacific, $S$. serrata is the most widespread of the four species and is most common where salinities are high (Keenan et al. 1998). It is the only species on islands more than 2,600 km east of Palau: Kosrae (Benstead et al. 2006, Bonine et al. 2008; C. Shelley, 2001, unpubl. data on feasibility of mangrove crab farming in Kosrae) and probably Pohnpei, FSM, where a Peace Corps Volunteer sensitive to the sentiment that there might be more than one species found no consistent variation in patterns of morphology (D. Perrine, 1978, unpubl. data). Only S. serrata is reported from both the FSM states of Chuuk and Yap (Lambeth and Santiago 2001a,b), but there may have been no attempt to distinguish the different species. A biogeographic gradient in mangrove crab species diversity therefore does exist across Micronesia, from Palau to Kosrae, with several details yet to be determined.

Scylla paramamosain and S. olivacea are generally more common under conditions of reduced salinity (Keenan et al. 1998, Walton et al. 2006a,b), and anecdotal evidence from Palauan crab trappers in 2004 indicated that these two species are more likely to be found farther upstream, in fresher water. These areas cannot be accessed easily by boat and can only be reached by crossing private property. Because the island of Babeldaob, where Ngaremeduu Bay is located, is both large and much eroded, it may be the only island in Micronesia with enough diversity of estuarine habitat to support more than one species of mangrove crab.

\section{Mangrove Crab Habitat}

All the species of mangrove trees we found around Ngaremeduu Bay except $C$. tagal also occur on Pohnpei and Kosrae, FSM, the easternmost high islands in Micronesia (approximately 2,600 and $3,100 \mathrm{~km}$, respectively, from Palau), where 10 species are found (N. Duke, pers. comm.). Bruguiera gymnorbiza, $S$. $a l b a$, and $R$. apiculata are the most abundant species in both Kosrae and Pohnpei, and $X y$ locarpus granatum is the fourth most abundant in Pohnpei (Cole et al. 1999). Mangrove trees in Palau and other western Micronesian islands tend to be significantly smaller in height and diameter than in Pohnpei and (especially) Kosrae, where rainfall is higher, typhoons are uncommon, and seasonality is absent (Cole et al. 1999). Nevertheless, the dominant species are similar.

Although mangrove crabs are widely cited as generalist feeders, and species composition of stands where they occur may not greatly affect habitat value, the correlation between burrow location and presence of $S$. alba, a relatively rare species in Palau, is worth noting. Sonneratia alba ranges broadly throughout the tropics, tending to become established in newly emerging sandy mud banks in lower intertidal zones throughout its broad range (Tomlinson 1986); it is found deeper in the mangrove forest where sediments have accumulated and extended the shoreline, but sexual reproduction there is apparently rare (e.g., Pinzón et al. 2003). Because Scylla serrata is also frequently found close to rivers (e.g., Barnes et al. 2002), it is possible that physical conditions such as tidal range or sediment type may favor both organisms similarly, making the correlation incidental. Nevertheless, habitat provided by branches fallen from 
large trees such as $S$. alba and by their characteristic hollow trunks appears to be attractive to mangrove crabs. Several times, two of us (K.C.E. and K.M.B.) observed mangrove crabs in the hollow stems of large, spreading $S$. alba trees in Kosrae that were often far from the shoreline. Presence of $S$. alba may be an important feature for $S$. serrata and perhaps for $S$. olivacea as well, which apparently constructs and uses permanent burrows (Walton et al. 2006b).

The Nekkeng River with its deep soils and abundance of large logs appeared to provide the best mangrove forest habitat for the crabs, as determined by burrow density. Many upland areas on Babeldaob were deforested, terraced, and probably planted to fruit trees before European contact in 1596; commercial export-oriented agriculture was practiced during the Japanese occupation from 1914 to 1944, including cultivation of sugarcane and pineapple in the Ngaremeduu Bay drainage area (Endress and Chinea 2001). From 1947 to 1992 , forest had increased from $50 \%$ to $63 \%$ cover on the uplands of the drainage area, primarily on sites where Japanese agriculture is likely to have been concentrated (Endress and Chinea 2001). An "island" in the mangroves adjacent to the Nekkeng River may have been farmed during that time and may have contributed sediments directly to the river, where they were subsequently deposited in the mangroves during high tides. However, since at least the late 1970s, enough sediments have accumulated at the mouth of both the Nekkeng and Ngatpang rivers to hinder boat access at low tide ( $\mathrm{T}$. Cole, pers. comm.). It is likely that geomorphological reasons are also responsible for the deeper soils along the Nekkeng River.

The presence of dead logs on the forest floor was probably due primarily to natural mortality: individual trees may snap off or uproot, and large branches may fall from $S$. alba trees (see Pinzón et al. 2003).

\section{Characteristics of Mangrove Crabs in Palau}

The maximum carapace widths of S. serrata in Ngaremeduu Bay were smaller than those reported elsewhere in Micronesia (230 $\mathrm{mm}$ in Kosrae, FSM [Ewel 2008]; $228 \mathrm{~mm}$ in Pohnpei, FSM [D. Perrine, 1978, unpubl. data]) but closer to those reported from Australia (206 mm [Heasman et al. 1985]) and South Africa (200 mm [Robertson and Kruger 1994; 209 mm [Hill 1994]). Scylla serrata may be smaller in Palau than in Kosrae because Ngaremeduu Bay lacks an extensive remote area such as the Utwe and Isra mangrove forests where the largest crabs in the Kosrae studies were found (Bonine et al. 2008, Ewel 2008).

Maximum size of $S$. paramamosain elsewhere ranges from 150 to $156 \mathrm{~mm}$ in Vietnam and Thailand (Overton and Macintosh 2002, Le Vay et al. 2007), considerably smaller than the individual captured in Ngaremeduu Bay. Scylla olivacea tends to be the smallest of the four species of mangrove crabs, suggesting that the individual we captured is relatively old, although a larger individual $(171 \mathrm{~mm})$ was reported from Thailand. The large size of the Palauan specimen may be attributed to the lack of harvest pressure farther upstream, where boats cannot easily go.

Some of the crabs we trapped in 19992000 may not have been S. serrata. However, none had the distinctly red color that distinguishes $S$. olivacea. The small incidence of species other than S. serrata in 2004 suggested that other mangrove crabs are either much less common or were not sampled adequately by our trapping effort. For instance, $S$. olivacea may become resident in the mangroves as it grows larger and may prefer the lower salinities farther upriver (Walton et al. 2006b). Because both S. olivacea and S. paramamosain are more common in mangroves exposed to lower salinity, our traps may have been too close to the mouth of the estuary to obtain a larger sample.

The burrow survey conducted in 19992000 included sites farther upstream than we were able to sample with traps. Some of the burrows may have been constructed and used by $S$. paramamosain or $S$. olivacea, more likely the latter because of its propensity for constructing burrows (Walton et al. 2006b). Both these species are generally smaller than S. serrata, however. In Vietnam, carapace 
width of $S$. paramamosain, which is probably the larger of the two species, ranged from 10 to $119 \mathrm{~mm}$, with a modal size of $40-49 \mathrm{~mm}$ for individuals captured in burrows (Walton et al. 2006b). Scylla olivacea is smaller, but it apparently uses burrows extensively as an adult (Estampador 1949), more so than $S$. paramamosain (Walton et al. 2006b), although the characteristics of these burrows are not known. We suspect that the 19 crabs we captured in burrows were $S$. serrata, because they were generally larger than any burrow $S$. olivacea is likely to have dug, the sizes of the burrows they occupied were much larger, and the burrows we monitored were neither permanent nor occupied by the same crab more than once. These burrows were apparently used for reproduction as well as protection and/or feeding.

Because burrows located in our study did not persist long and were seldom occupied by more than one crab, we believe that abundance for $S$. serrata can be estimated from burrow density in Ngaremeduu Bay (see Warren 1990). Our estimate of 40 S. serrata $\mathrm{ha}^{-1}$ is intermediate between two crabs per hectare in Deception Bay in northern Australia (Hill et al. 1982) and in Pohnpei, FSM (D. Perrine, 1978, unpubl. data), and 80 crabs per hectare in South Africa (Hill 1975) and in an estuarine area in Queensland, Australia (Williams and Hill 1982). It is twice the density estimated on Kosrae, FSM (21 crabs per hectare [K.M.B., K.C.E., and M. Palik, unpubl. data]).

\section{Management Implications}

Our measures of catch per unit effort were comparable with values from two similar studies in Kosrae: 0.59 crab trap night ${ }^{-1}$ (95\% CI: $0.511,0.674)$ over a 1.5 yr period from 1998 to 2001 (Bonine et al. 2008) and 0.69 crab trap night ${ }^{-1}$ during a total of 2 months at different times across a 4-month interval in 2004 (Ewel 2008). The data from the two collections in the study reported here are not sufficient to draw any conclusions about trends in Ngaremeduu Bay, but they do indicate similar results across Micro- nesia where comparable trapping methods have been used.

Although sizes of male and female mangrove crabs captured in 1999-2000 did not differ significantly from those trapped in 2004, the largest quartile in the later sample was significantly smaller than in the earlier sample, and maximum sizes, already smaller than elsewhere in Micronesia, were also smaller than in the earlier trapping. Nevertheless, the legally harvestable size in Palau (6 inches, or $152 \mathrm{~mm}$ ) is very close to the overall mean and median of the crabs we captured in 2004. Although there are still large crabs in Ngaremeduu Bay, catch restrictions and more recently a 5 -month harvest cessation have not been entirely successful at maintaining a stable population size. Establishment of additional marine protected areas and banning the harvest of female crabs entirely may be possible additional measures.

Ngaremeduu Bay would be a useful site for demonstrating how different mangrove crab species partition their habitat in a relatively small area. The imminent increase in human population density with increased road access and activity surrounding the new capitol complex promises to bring more demand for mangrove crabs and perhaps easier overland access to Ngaremeduu Bay. These changes may soon confound or destroy these relationships, making it compelling that such studies be conducted as soon as possible.

\section{ACKNOWLEDGMENTS}

We thank Thomas J. Smith III for valuable assistance in study design, Thomas G. Cole for data analysis and pertinent observations about Ngaremeduu Bay, and Gilbert Demei and Alma Ridep-Morris for logistic support. Peter Osilik and Calvin Surangel assisted with field work. We thank the Peace Corps for supporting participation by S.R. and B.M. James Baldwin and Sylvia Mori advised us on statistical analysis. Dennis O'Dowd, Jurgenne Primavera, Colin Shelley, Thomas J. Smith III, Mark Walton, and Meryl Williams provided constructive comments on an early version of the manuscript. 


\section{Literature Cited}

Atherton, J., ed. 2007. Polynesia-Micronesia biodiversity hotspot. Critical ecosystem profile. Ecosystem Partnership Fund. Conservation International-Melanesia Center for Biodiversity Conservation. Arlington, Virginia.

Barnes, D. K. A., N. K. Dulvy, S. H. Priestly, W. R. T. Darwall, V. Choisell, and M. Whittington. 2002. Fishery characteristics and abundance estimates of the mangrove crab Scylla serrata in southern Tanzania and northern Mozambique. S. Afr. J. Mar. Sci. 24:19-25.

Benstead, J. P., J. G. March, B. Fry, K. C. Ewel, and C. M. Pringle. 2006. Testing IsoSource: Stable isotope analysis of a tropical fishery with diverse organic matter sources. Ecology 87:326-333.

Bonine, K. M., E. P. Bjorkstedt, K. C. Ewel, and M. Palik. 2008. Population characteristics of the mangrove crab Scylla serrata (Decapoda: Portunidae) in Kosrae, Federated States of Micronesia: Effects of harvest and implications for management. Pac. Sci. 62:1-19.

Brown, I. W. 1993. Mangrove crabs. Pages 611-642 in A. Wright and L. Hill, eds. Nearshore marine resources of the South Pacific: Information for fisheries management and development. Forum Fisheries Agency, Honiara, Solomon Islands.

Cole, T. G., K. C. Ewel, and N. N. Devoe. 1999. Structure of mangrove trees and forests in Micronesia. For. Ecol. Manage. 117:95-109.

Cole, T. G., M. C. Falanruw, C. D. MacLean, C. D. Whitesell, and A. H. Ambacher. 1987. Vegetation survey of the Republic of Palau. U.S. For. Serv. Resour. Bull. PSW-22.

Crombie, R. I., and G. K. Pregill. 1999. A checklist of the herpetofauna of the Palau Islands (Republic of Belau), Oceania. Herpetol. Monogr. 13:29-80.

Endress, B. A., and J. D. Chinea. 2001. Landscape patterns of tropical forest recovery in the Republic of Palau. Biotropica 33:555-565.
Estampador, E. P. 1949. Studies on Scylla (Crustacea: Portunidae). I. A revision of the genus. Philipp. J. Sci. 78:95-108.

Ewel, K. C. 2008. Mangrove crab (Scylla serrata) populations may sometimes best be managed locally. J. Sea Res. 59:114120.

Heasman, M. P., D. R. Fielder, and R. K. Shepard. 1985. Mating and spawning in the mudcrab, Scylla serrata (Forskål) (Decapoda: Portunidae) in Moreton Bay, Queensland. Aust. J. Mar. Freshwater Res. 36:773-783.

Hill, B. J. 1975. Abundance, breeding, and growth of the crab Scylla serrata in two South African estuaries. Mar. Biol. (Berl.) 32:119-126.

1994. Offshore spawning by the portunid crab Scylla serrata (Crustacea: Decapoda). Mar. Biol. (Berl.) 120:379-384.

Hill, B. J., M. J. Williams, and P. Dutton. 1982. Distribution of juvenile, subadult and adult Scylla serrata (Crustacea: Portunidae) on tidal flats in Australia. Mar. Biol. (Berl.) 69:117-120.

Hyland, S. J., B. J. Hill, and C. P. Lee. 1984. Movement within and between different habitats by the portunid crab Scylla serrata. Mar. Biol. (Berl.) 80:57-61.

Keenan, C. P., P. J. F. Davie, and D. L. Mann. 1998. A revision of the genus Scylla De Haan, 1833 (Crustacea: Decapoda: Brachyura: Portunidae). Raffles Bull. Zool. 46:217-245.

Lambeth, L., and E. Santiago. 2001a. An assessment of the role of women in fisheries in Chuuk, Federated States of Micronesia. Field Report No. 4, Secretariat of the $\mathrm{Pa}$ cific Community, Noumea, New Caledonia.

. 2001b. An assessment of the role of women in fisheries in Yap, Federated States of Micronesia. Field Report No. 5, Secretariat of the Pacific Community, Noumea, New Caledonia.

Le Vay, L., V. N. Ut, and M. Walton. 2007. Population ecology of the mud crab Scylla paramamosain (Estampador) in an estuarine mangrove system: A mark-recapture study. Mar. Biol. (Berl.) 151:1127-1135. 
Milliken, G. A., and D. E. Johnson. 1992. Analysis of messy data. Chapman \& Hall, New York.

Overton, J. L., and D. J. Macintosh. 2002. Estimated size at sexual maturity for female mud crabs (genus Scylla) from two sympatric species within Ban Don Bay, Thailand. J. Crustacean Biol. 22:790-797.

Pinzón, Z. S., K. C. Ewel, and F. E. Putz. 2003. Gap formation and seedling regeneration in mangrove forests in Micronesia. J. Trop. Ecol. 19:143-153.

Ridep-Morris, A. 2000. Management plan for the Ngaremeduu Conservation Area. Ngaremeduu Conservation Area Project, Republic of Palau.

Robertson, W. D., and A. Kruger. 1994. Size at maturity, mating and spawning in the portunid crab Scylla serrata (Forskål) in Natal, South Africa. Estuarine Coastal Shelf Sci. 39:185-200.

Robertson, W. D., and S. E. Piper. 1991. Population estimates of the crab Scylla serrata (Forskål, 1755) (Decapoda, Portunidae) in two closed estuaries in Natal, South-Africa, from mark-recapture methods. S. Afr. J. Mar. Sci. 11:193-202.

SAS Institute, Inc. 2000. The SAS system, version 8. SAS Institute, Inc. Cary, North Carolina.
.2000-2004. The SAS system, version 9.1. SAS Institute, Inc. Cary, North Carolina.

Stephenson, W., and B. Campbell. 1960. The Australian portunids (Crustacea: Portunidae). IV: Remaining genera. Aust. J. Mar. Freshwater Res. 11:73-122.

Tomlinson, P. B. 1986. The botany of mangroves. Cambridge University Press, Cambridge, United Kingdom.

Walton, M. E., L. Le Vay, J. H. Lebata, J. Binas, and J. H. Primavera. 2006a. Seasonal abundance, distribution, and recruitment of mud crabs (Scylla spp.) in replanted mangroves. Estuarine Coastal Shelf Sci. 66:493-500.

Walton, M. E., L. Le Vay, L. M. Truong, and V. N. Ut. 2006b. Significance of mangrove-mudflat boundaries as nursery grounds for the mud crab, Scylla paramamosain. Mar. Biol. (Berl.) 149:11991207.

Warren, J. H. 1990. The use of open burrows to estimate abundances of intertidal estuarine crabs. Aust. J. Ecol. 15: 277-280.

Williams, M. J., and B. J. Hill. 1982. Factors influencing pot catches and population estimates of the portunid crab Scylla serrata. Mar. Biol. (Berl.) 71:187-192. 